\title{
Technological parameters of ceramics creation on the basis of slavsonite
}

G. V. LISASCHUK - National Technical University, Kharkiv Polytechnic Institute, Ukraine - lisachuk@ kpi.kharkov

R. V. KRYVOBOK - National Technical University, Kharkiv Polytechnic Institute, Ukraine - krivobok491@gmail.com

A. V. ZAKHAROV - National Technical University, Kharkiv Polytechnic Institute, Ukraine - zakharovartem106@gmail.com

E. V. CHEFRANOV - National Technical University, Kharkiv Polytechnic Institute, Ukraine - eugene@chefranov.name

O. M. LAPUZINA - National Technical University, Kharkiv Polytechnic Institute, Ukraine - elapuzina@gmail.com

V. V. VOLOSHCHUK - National Technical University, Kharkiv Polytechnic Institute, Ukraine - valenty93vol@gmail.com

N. N. SAMOILENKO - National Technical University, Kharkiv Polytechnic Institute, Ukraine - samoilenko@kpi.kharkov.ua

Érkezett: 2018. 11. 27. - Received: 27. 11. 2019. - https://doi.org/10.14382/epitoanyag-jsbcm.2019.9

\section{Abstract}

The rationalization of technological parameters of products' manufacturing based on previously developed compositions of Slavsonite ceramics using a full-factor experiment of $2^{3}$ type was studied. Equations of regression that describe adequately the dependencies of selected reviews (water absorption, dielectric permittivity, compressive strength) from grinding time and firing temperature were obtained. Based on the conducted research, a technological scheme for the manufacture of simple-shaped ceramic products that are capable of performing the functions of protective radio-transparent structural elements has been developed.

Keywords: slavsonite, radiotransparent ceramics, full-factor experiment, dielectric permittivity, dielectric loss tangent, water absorption, compressive strength, pressing pressure, grinding time, firing temperature

Kulcsszavak: szlavszonit, sugárzás áteresztố kerámiák,teljes faktorális kísérlet, dielektromos permittivitás, dielektromos veszteségi tangens, vízfelvétel, nyomószilárdság, préselési nyomás, csiszolási idő, égetési hômérséklet

George Lisaschuk Doctor of Sciences, full Professor. Specialist in material sciences of resource saving and energysaving technologies, new structural ceramic materials and coatings. Head of Research department of NTU "KhPl".

Ruslan Krivobok Ph.D, Senior researcher. Specialist in material sciences of new special-purpose ceramic materials and coatings. Deputy Head of Scientific and Research Part NTU "KhPl"

Artem Zakharov Ph.D, NTU "KhPl". Fields of interests: development and physico-chemical properties of radiotransparent ceramic, functional materials.

Yevgen Chefranov Ph.D. student, NTU "KhPl”, Department of technology of ceramics, refractories, glass and enamels. Specializes in the study of radiotransparent ceramic materials.

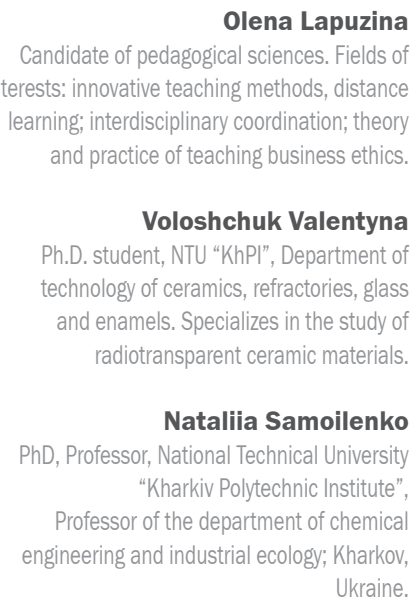
Ukraine.

\section{Introduction}

The prospect of products' manufacturing based on Slavsonite (strontium aluminosilicate $-\mathrm{SrAl}_{2} \mathrm{Si}_{2} \mathrm{O}_{8}$ ) is in the ability to combine a complex of dielectric and physical-mechanical characteristics of this material, such as radiotransparency, high strength, temperature resistance, and to have a low cost of raw materials. Slavsonite, besides the low dielectric permittivity value $\varepsilon \sim 6.2 \ldots 6.8$, has the lowest dielectric loss $\tan \delta \sim 0.0001 \ldots$ 0.0002 from among the crystalline phases, suitable for creating radioceramics [1].

Such materials are most often used when creating protection elements for aircraft antenna transmitters under high temperature and mechanical loads. For radiotransparent ceramic materials, low dielectric losses $(\tan \delta<0.001)$ and high stability of properties with temperature changes are typical. For example, the dielectric permittivity of sitalls does not change by more than $\pm 1 \%$, and the tangent of dielectric loss increases by no more than $\pm 20 \%$ when the temperature changes from $60^{\circ}$ to $+1,200^{\circ} \mathrm{C}[2]$.

The relevance of the study is creation of high-strength products of simple shape from the developed masses of radio transparent material based on the crystalline phase of Slavsonite.

\section{Analysis of literature data and problem statement}

The problem of creating densely sintered materials, firstly, lies in the difficulty of consolidating the dispersed powder after its synthesis. Scientists from many countries are involved in solving this problem, using various methods.

Researchers in the study [3] considered titanium oxide, zircon and glass as additives for sintering glass ceramics of cordierite composition. It is established that the minimum values of porosity (2-5\%) are samples with the addition of glass, and its sufficient amount is 5 weight \% (wt.\%).

The author [4] obtained stoichiometric Slavsonite glass ceramics using cold isostatic pressing and sintering. In this case, the specific gravity of the material reached $94 \%$ and $97 \%$ of the theoretical.

The effect of various heat treatment modes on the sintering density of slavsonite glass ceramics is described in the study [5]. This work is relevant because the density of the material obtained becomes a critical factor in its application. For this study, the strontium aluminosilicate composition was used, which forms monoclinic Slavsonite as the primary crystalline phase already at a temperature of $1,200^{\circ} \mathrm{C}$. 
In the study [6] the synthesis of Slavsonite by the sol-gel method and the preparation of high-density glass ceramics was carried out. The peaks of this crystalline phase begin to appear clearly on the radiograph of the synthesized material already at a temperature of $1,100{ }^{\circ} \mathrm{C}$ and at $1,250{ }^{\circ} \mathrm{C}$ the Slavsonite of the monoclinic syngony makes up $100 \%$ of the entire crystalline phase.

At the previous stages of research, the influence of the method of magnetic-pulse pressing (MPP) was studied [7]. The apparent density determined the effect of this method on the degree of sintering of the samples and the completion of the Slavsonite formation, and the amount of $\mathrm{SrAl}_{2} \mathrm{Si}_{2} \mathrm{O}_{8}$ in the phase of the samples' composition annealed at a temperature of $1,250^{\circ}, 1,350^{\circ}$ and $1,450{ }^{\circ} \mathrm{C}$, depending on the intensity of the impact action (number of cycles). According to research results, compared with the properties of the samples created by the method of static semi-dry pressing, it was found that the use of MPP significantly improves the characteristics of sintering the samples: the effect of 6 cycles of percussion and firing at a temperature of $1,250{ }^{\circ} \mathrm{C}$ is equivalent to a temperature rise on $120{ }^{\circ} \mathrm{C}$. This method of formation on the processes of formation of the slavsonite phase at a given burning temperature is almost negligible: the increase of the Slavsonite amount using MPP does not exceed $2 \%$.

It is important to note that the synthesis of Slavsonite takes place in the presence of a liquid phase in the above works. Liquid phase sintering is the most common process in ceramics technology, especially with the participation of aluminosilicates. The melt formed during ceramic firing plays the main role; it dissolves the raw materials and is the source of the new crystalline phase. Therefore, it is possible to control the synthesis process by changing the characteristics of the melt (viscosity, surface tension, activity).

In the study [8] the effect of additives of $\mathrm{B}_{2} \mathrm{O}_{3}$ and $\mathrm{P}_{2} \mathrm{O}_{5}$, which are glass-forming oxides was studied, but in this case they also played the role of mineralizers, reducing the temperature of crystallization to the beginning of Slavsonite $1,020^{\circ} \mathrm{C}$.

In the study [4] the preparation of high-strength ceramic materials with low values of dielectric properties is described. Moreover, it is said that the additives $\mathrm{B}_{2} \mathrm{O}_{3}, \mathrm{LiF}, \mathrm{Cr}_{2} \mathrm{O}_{3}$, and $\mathrm{ZrSiO}_{3}$ contribute to the transition of Slavsonite from the hexagonal form to the stable monoclinic form. This is due to the cracking of the ceramic body, possible at the stage of cooling during the polymorphic transformation of the hexagonal form, which takes place with an increase in volume on $3 \%$.

Analyzing the methods of obtaining materials on the basis of Slavsonite are considered, it has been found that in most cases they are obtained by glass-ceramic technology, which requires additional energy costs for the transition of the hexagonal form of Slavsonite to the monoclinic form. In previous studies in studies [1,9] the compositions of Slavsonite ceramics were developed, corresponding to the specified indicators of properties. Thus, in further studies it is advisable to carry out the selection of the optimal method of slavsonite powder consolidating to create products of simple form.

\section{The purpose and objectives of the study}

The aim of the study was the development of technological parameters for obtaining simple-shaped products from the developed masses of densely sintered, radio-transparent material with high mechanical properties with two-stage ceramic technology based on the crystalline phase of Slavsonite.

To achieve the goal, the following tasks were set:

- to choose the optimal binder and its amount from among the solutions of dextrin and methylcellulose;

- to investigate the influence of the grinding mode of the synthesized material, the pressing pressure and the firing temperature on the studied properties;

- to develop a technological scheme for the manufacture of simple-shaped products from the developed ceramic radio transparent materials on the basis of the conducted complex of studies.

\section{Materials and research methods}

Selection of the binder material was carried out by a separate experiment, while other parameters were made in a fully factorial experiment. The pre-synthesized ceramic material based on the crystalline phase of Slavsonite was ground in a planetary mill at 400 revolutions per minute with a grinding time of 15 minutes. For the study, dextrin and methylcellulose were selected as a binder in an amount from 1 to 3 wt. \% with pace of $0.5 \%$ for dextrin and in an amount from 2 to 4 wt. \% with pace of $0.5 \%$ for methylcellulose. The amount of binder was injected with more than 100 wt. \% of the mixture predissolved and aged for 24 hours in water in an amount equal to $8 \%$ of the humidity of the press powder. Samples were formed in the form of cylinders with a diameter and height of $25 \mathrm{~mm}$, at a pressing pressure of $30 \mathrm{MPa}$ with the previous pseudogranulation at a pressure of $50 \mathrm{MPa}$. Samples were kept for 24 hours at room temperature, after which part of the series was dried to a moisture content of not more than $0.5 \%$ and burned at a temperature of $1,300{ }^{\circ} \mathrm{C}$, and another part of the series was used to determine the strength of the raw material. Determination of strength was performed by the method of compression and the effect of the binder and its amount on the degree of water absorption was determined on the scorched samples. The results of both studies are shown in Table 1.

\begin{tabular}{|c|c|c|c|c|c|c|c|c|c|c|}
\hline \multirow{3}{*}{ Properties } & \multicolumn{10}{|c|}{ Binder additive and its content, wt.\% } \\
\hline & \multicolumn{5}{|c|}{ Dextrin } & \multicolumn{5}{|c|}{ Methylcellulose } \\
\hline & 1 & 1.5 & 2 & 2.5 & 3 & 2 & 2.5 & 3 & 3.5 & 4 \\
\hline $\begin{array}{l}\text { Compressive } \\
\text { strength of raw } \\
\text { material, MPa }\end{array}$ & 0.31 & 0.54 & 0.76 & 0.97 & 1.09 & 0.92 & 1.75 & 2.05 & 2.18 & 2.33 \\
\hline $\begin{array}{l}\text { Water } \\
\text { absorption,\% }\end{array}$ & 0.14 & 0.29 & 0.33 & 0.58 & 0.75 & 0.19 & 0.27 & 0.31 & 0.57 & 0.9 \\
\hline $\begin{aligned} \text { Table } 1 \text { Result } \\
\text { 1. táblázat A kötó }\end{aligned}$ & lyag $h$ & $\begin{array}{l}\text { study of } \\
\text { zatása a }\end{array}$ & $\begin{array}{l}f \text { the effe } \\
\text { a ered } n\end{array}$ & $\begin{array}{l}\text { fect of } \\
\text { mény. }\end{array}$ & re & & & & & \\
\hline
\end{tabular}

The data obtained indicate that the optimal binder is methylcellulose in an amount of $3 \mathrm{wt} . \%$, since an increase in its amount with an increase in strength will lead to an increase in the value of water absorption by more than $0.5 \%$. 


\section{Experiment Planning}

For carrying out an experiment of establishing the best technological parameters, a full-factor experiment of type $2^{3}$ was used, in which factors were grinding time, pressing pressure and heat treatment temperature.

To clarify the experiment, it was decided that a point with the following zero values of the factors should be chosen as the center of the plan: grinding time is 15 minutes; pressing pressure is $30 \mathrm{MPa}$; firing temperature is $1,325^{\circ} \mathrm{C}$. The interval of the grinding time varying is 5 minutes, the pressing pressure is $10 \mathrm{MPa}$, and the firing temperature is $25^{\circ} \mathrm{C}$. Figure 1 illustrates the arrangement of experiments of type $2^{3}$ in threedimensional space.

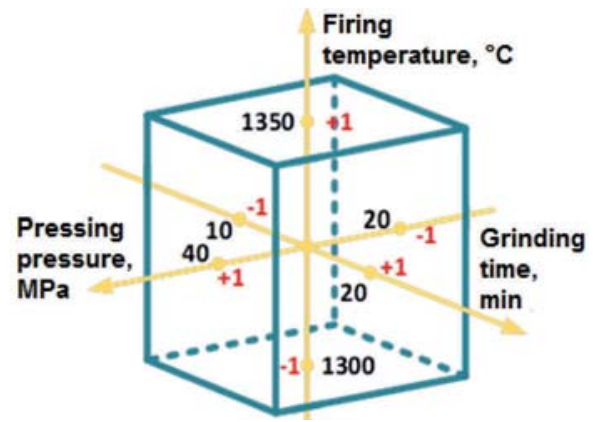

Fig. 1 The arrangement of experiments of type $2^{3}$ in three-dimensional space 1. ábra 23 háromfaktoros teljes faktorális kísérleti tervelrendezés három dimenziós térben ábrázolva

In accordance with the developed natural plan of the experiment (Table 2), samples by the classical technology were obtained. The grinding of the synthesized mass was carried out in a planetary mill to a residue on sieve №0063 not more than $1.5 \%$, it was thoroughly mixed with a binder solution, and the humidity of the press powder was $8 \%$.

\begin{tabular}{|c|c|c|c|c|}
\hline \multirow[b]{2}{*}{$\begin{array}{l}\text { Composition } \\
\text { cipher }\end{array}$} & \multirow[b]{2}{*}{$\begin{array}{c}\text { Cipher } \\
\text { sample } \\
\text { in the series }\end{array}$} & \multicolumn{3}{|c|}{ Factors in natural form } \\
\hline & & $\begin{array}{l}\text { Grinding } \\
\text { time } \\
x, \text { min }\end{array}$ & $\begin{array}{c}\text { Pressing } \\
\text { pressure } \\
\text { y, MPa }\end{array}$ & $\begin{array}{c}\text { Firing } \\
\text { temperature } \\
\mathbf{z},{ }^{\circ} \mathbf{C}\end{array}$ \\
\hline \multirow{9}{*}{$\begin{array}{l}\text { Composition } \\
\text { "O" }\end{array}$} & $0-8$ & 20 & 40 & 1,350 \\
\hline & $0-7$ & 10 & 40 & 1,350 \\
\hline & $0-6$ & 20 & 20 & 1,350 \\
\hline & $0-5$ & 10 & 20 & 1,350 \\
\hline & $0-4$ & 20 & 40 & 1,300 \\
\hline & $0-3$ & 10 & 40 & 1,300 \\
\hline & $0-2$ & 20 & 20 & 1,300 \\
\hline & $0-1$ & 10 & 20 & 1,300 \\
\hline & $0-9$ & 15 & 30 & 1,325 \\
\hline \multirow{9}{*}{$\begin{array}{l}\text { Composition } \\
\text { "2" }\end{array}$} & $2-8$ & 20 & 40 & 1,350 \\
\hline & $2-7$ & 10 & 40 & 1,350 \\
\hline & $2-6$ & 20 & 20 & 1,350 \\
\hline & $2-5$ & 10 & 20 & 1,350 \\
\hline & $2-4$ & 20 & 40 & 1,300 \\
\hline & $2-3$ & 10 & 40 & 1,300 \\
\hline & $2-2$ & 20 & 20 & 1,300 \\
\hline & $2-1$ & 10 & 20 & 1,300 \\
\hline & $2-9$ & 15 & 30 & 1,325 \\
\hline
\end{tabular}

Table 2 Plan of the experiment in its natural form

2. táblázat A kísérleti terv eredeti formájában
The formation of semi-finished products took place in two stages, the first was granulation, formation of briquettes at a pressure of $50 \mathrm{MPa}$, followed by “wiping” through a sieve № 05; the second stage included pressing of the specified samples at a pressure of 20,30 and $40 \mathrm{MPa}$. The next steps were drying in a drying oven and firing at a temperature of $1,300^{\circ}, 1,325^{\circ}$ and $1350^{\circ} \mathrm{C}$ with an exposure of one hour at the maximum temperature. The plan-matrix with natural values of factors according to the selected interval of variation is shown in Table 2.

\section{The research results of indicators of obtained ceramic samples}

During the experiment, the main technological properties of radiotransparent ceramics, such as water absorption, dielectric permittivity and flexural strength were determined (Table 3).The obtained results were processed with the Excel software application. For each experiment series, adequate third order equations that characterize the dependencies were obtained:

"grinding time - pressing pressure - firing temperature water absorption",

"grinding time - pressing pressure - firing temperature dielectric permittivity",

"grinding time - pressing pressure - firing temperature flexural strength".

Dependencies with coded factors for different series are: for a series of composition " 0 ":

$\mathrm{W}, \%=0.579-0.155 \cdot \mathrm{x}-0.263 \cdot \mathrm{y}-0.119 \cdot \mathrm{z}+0.063 \cdot \mathrm{y} \cdot \mathrm{z}-$

$0.019 \cdot \mathrm{x} \cdot \mathrm{y} \cdot \mathrm{z}$

$\varepsilon=6.565+0.081 \cdot x+0.059 \cdot y+0.158 \cdot z+0.032 \cdot x \cdot y+0.023 \cdot y \cdot z$

$\sigma_{\mathrm{fl}}, \mathrm{MPa}=48.69+6.233 \cdot \mathrm{x}+3.612 \cdot \mathrm{y}+9.841 \cdot \mathrm{z}+2.019 \cdot \mathrm{x} \cdot \mathrm{y}+$

$0.983 \cdot \mathrm{x} \cdot \mathrm{z}+0.809 \cdot \mathrm{y} \cdot \mathrm{z}+0.12 \cdot \mathrm{x} \cdot \mathrm{y} \cdot \mathrm{z}$

for a series of composition " 2 ":

$\mathrm{W}, \%=0.079-0.022 \cdot \mathrm{x}-0.066 \cdot \mathrm{y}-0.007 \cdot \mathrm{z}+0.01 \cdot \mathrm{x} \cdot \mathrm{y}+0.01 \cdot \mathrm{x} \cdot \mathrm{z}$

$\varepsilon=6.327+0.053 \cdot x+0.045 \cdot y+0.027 \cdot z+0.029 \cdot x \cdot z+0.021 \cdot y \cdot z+$ $0.029 \cdot \mathrm{x} \cdot \mathrm{y} \cdot \mathrm{z}$

$\sigma_{\mathrm{fl}}, \mathrm{MPa}=50.875+5.371 \cdot \mathrm{x}+1.524 \cdot \mathrm{y}+0.798 \cdot \mathrm{z}+1.977 \cdot \mathrm{x} \cdot \mathrm{y}+$

$0.703 \cdot \mathrm{x} \cdot \mathrm{z}-0.348 \cdot \mathrm{y} \cdot \mathrm{z}+1.499 \cdot \mathrm{x} \cdot \mathrm{y} \cdot \mathrm{z}$

For equations $1-6$ :

$$
\begin{gathered}
x=\frac{\tau(\text { Grinding time, } \mathrm{min} .)-15}{5} \\
y=\frac{\mathrm{P}(\text { Pressing pressure, } \mathrm{MPa})-30}{10} \\
z=\frac{t\left(\text { Firing temperature, }{ }^{\circ} \mathrm{C}\right)-1,325}{25}
\end{gathered}
$$

The analysis of the obtained regression equations for the two compositions allows us to estimate the influence of the technological parameters of obtaining the sintered material with high strength characteristics. Thus, the influence of factors on water absorption for both compositions is similar: an increase in the grinding time increases the water absorption 
values, and the pressing pressure and the firing temperature decrease the water absorption values. Negative coefficients with factors for indicators of the dielectric permittivity of both compositions are observed. This indicates that with increasing the values of the studied parameters, the dielectric permittivity will also increase, which is most likely, caused from the glass phase increasing. Moreover, it should be noted the different importance of the parameters when affecting the dielectric constant: for the composition " 0 " the more important parameter is the sintering temperature, whereas for the composition "2" the more important parameter is the grinding time. For clarity, the diagram (Fig. 2) shows the significance of the influence of parameters on the studied properties. The effect of factors on the bending strength indices for both compositions is completely different. Only the effect of grinding time increasing is common, which is expressed as a strength decreasing. The increasing of pressing pressure and the firing temperature have a positive effect on the strength for the composition " 0 ", whereas increasing of these factors reduce the strength characteristics for the composition " 2 ".

From the diagram in Figure 2, it can be seen that the significance of factors is more different for individual properties as compared with significance for research compositions. Water absorption for both compositions is most influenced by pressing pressure. Whereas, the dielectric permittivity and strength characteristics of the composition " 2 " are influenced more by the grinding time, at the same time the dielectric permittivity and strength characteristics of the composition " 0 " are influenced more by the firing temperature. This fact can be explained by a large amount of glass phase in the synthesized material, which contributes to a more dispersed powder during the same grinding time.

\begin{tabular}{|c|c|c|c|c|}
\hline \multirow[b]{2}{*}{$\begin{array}{l}\text { Composition } \\
\text { cipher }\end{array}$} & \multirow{2}{*}{$\begin{array}{l}\text { Cipher } \\
\text { sample } \\
\text { in the } \\
\text { series }\end{array}$} & \multicolumn{3}{|c|}{ Sample Properties } \\
\hline & & $\begin{array}{c}\text { Water } \\
\text { absorption } \\
\text { w, \% }\end{array}$ & $\begin{array}{c}\text { Dielectric } \\
\text { permittivity, } \\
\varepsilon\end{array}$ & $\begin{array}{c}\text { Bending } \\
\text { Power Limit, } \\
\text { б MIIa }\end{array}$ \\
\hline \multirow{9}{*}{$\begin{array}{l}\text { Composition } \\
\text { «0" }\end{array}$} & $0-8$ & 0.08 & 6.89 & 72.3 \\
\hline & $0-7$ & 0.44 & 6.72 & 53.6 \\
\hline & $0-6$ & 0.53 & 6.69 & 59.2 \\
\hline & $0-5$ & 0.79 & 6.59 & 49.0 \\
\hline & $0-4$ & 0.23 & 6.58 & 48.8 \\
\hline & $0-3$ & 0.51 & 6.30 & 34.5 \\
\hline & $0-2$ & 0.86 & 6.42 & 39.4 \\
\hline & $0-1$ & 1.19 & 6.32 & 32.7 \\
\hline & $0-9$ & 0.57 & 6.34 & 47.1 \\
\hline \multirow{9}{*}{$\begin{array}{l}\text { Composition } \\
\text { «" }\end{array}$} & $2-8$ & 0 & 6.52 & 62.4 \\
\hline & $2-7$ & 0 & 6.32 & 48.3 \\
\hline & $2-6$ & 0.12 & 6.31 & 53.1 \\
\hline & $2-5$ & 0.17 & 6.27 & 47.9 \\
\hline & $2-4$ & 0 & 6.35 & 57.1 \\
\hline & $2-3$ & 0.05 & 6.30 & 46.8 \\
\hline & $2-2$ & 0.11 & 6.34 & 52.4 \\
\hline & $2-1$ & 0.19 & 6.21 & 44.0 \\
\hline & $2-9$ & 0.06 & 6.22 & 49.5 \\
\hline
\end{tabular}

Table 3 Properties of the experimental compositions 3. táblázat A kísérleti összetételek tulajdonságai

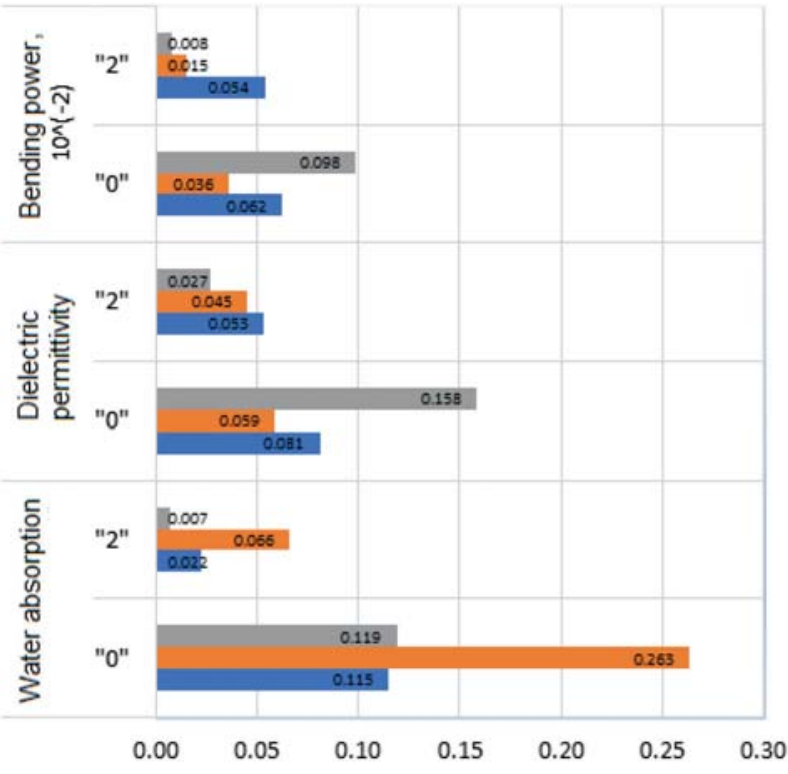

mFiring temperature, ${ }^{\circ} \mathrm{C}(\mathrm{z})$ =Pressing pressure, $\mathrm{MPa}(\mathrm{y})$ = Grinding time, $\min (\mathrm{x})$

Fig. 2 Comparative chart of the coefficients for individual factors in the "technological parameters - properties" equation

2. ábra Összehasonlitó diagram a technológiai paraméterek - tulajdonságok egyenletében található egyes tényezők együtthatóiról
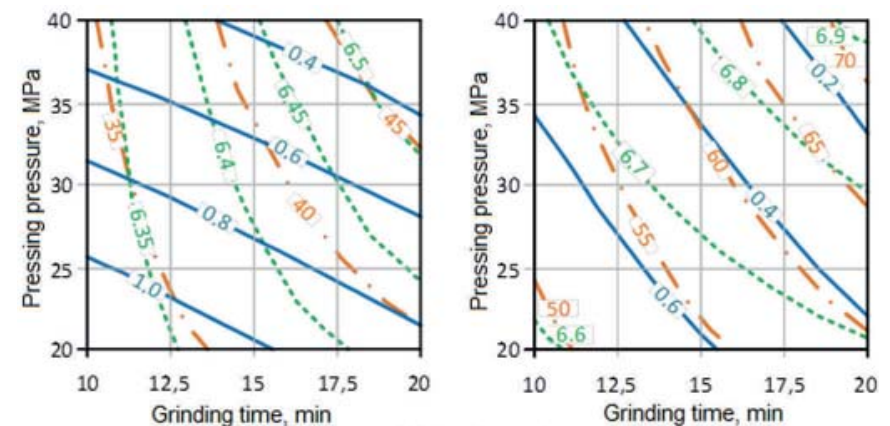

Water absorption W\%

Dielectric permittivity,

- - - Bending power $\mathrm{\sigma}_{\mathrm{wr}}, \mathrm{MPa}$

Fig. 3 Dependence of water absorption, dielectric constant and power limits for bending samples of the composition "0", scorched at temperatures 1,300 and $1,350^{\circ} \mathrm{C}$ from technological parameters

3. ábra 1300 és $1350^{\circ} \mathrm{C}$-on égetett "0"-s összetételu hajlitó minták függősége a vízfelvételtöl, dielektromos állandótól és teljesítménylimitektöl

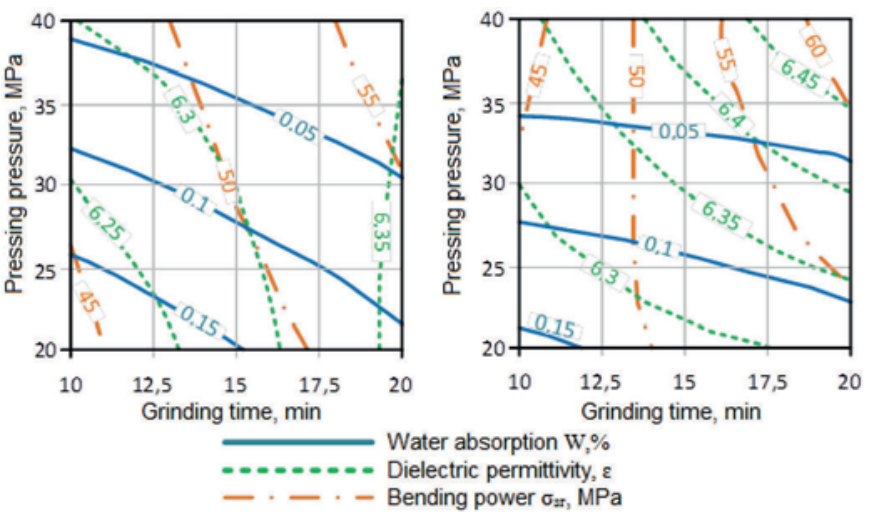

Fig. 4 Dependence of water absorption, dielectric permittivity and tensile strength in bending of samples of the composition " 2 " scorched at temperatures $1,300^{\circ}$ and $1,350^{\circ} \mathrm{C}$ from technological parameters

4. ábra 1300 és $1350^{\circ} \mathrm{C}$-on égetett " 2 "-s összetételü hajlitó minták függősége a vízfelvételtől, dielektromos állandótól és teljesítménylimitektöl 
The use of the obtained models allows predicting the indicators of water absorption, dielectric permittivity and strength of materials with sufficient accuracy that will be manufactured using the selected compositions and according to the specified technological parameters.

For graphical interpretation of the obtained data, the diagrams with lines of equal values for water absorption, dielectric permittivity and bending strength were constructed for extreme values of the firing temperature factor. Excel software was used for this purpose (Fig. 3 and 4).

The results of the experiment showed that within the selected interval of variation of technological parameters, an increasing of the duration of synthesis products grinding, pressure of semi-dry pressing and firing temperature of products the water absorption is decreasing, the flexural strength is increasing, when storing dielectric permittivity values within 6.25 ... 6.9. This effect is caused by the amount of melt that compacts the material increasing. The influence of individual parameters on the properties of samples of ceramics of the composition " 2 " is more pronounced: strength indicators are more influenced by grinding time, and water absorption is more influenced by pressing pressure; it is especially clearly observed with the firing temperature increasing to $1,350{ }^{\circ} \mathrm{C}$.

Based on the conducted research, a technological scheme for the simple-shaped products manufacturing from developed ceramic radiotransparent materials has been developed (Fig. 5).

\begin{tabular}{|c|c|c|c|}
\hline \multicolumn{4}{|c|}{ Preparation of the initial components of the charge } \\
\hline $\begin{array}{l}\text { Technical } \\
\text { Alumina }\end{array}$ & Quartz & $\begin{array}{l}\text { Strontium } \\
\text { Carbonate }\end{array}$ & $\begin{array}{l}\text { Intensifying } \\
\text { Additive }\end{array}$ \\
\hline Dosing & Dosing & Dosing & Dosing \\
\hline \multicolumn{4}{|c|}{ Grinding (ball mill to complete passage through sieve № 0063) } \\
\hline \multicolumn{4}{|c|}{ Moistening the press powder with a dextrin solution $(\mathrm{W}=8 \%)$} \\
\hline \multicolumn{4}{|c|}{ Formation (semi-dry pressing, $20 \mathrm{MPa}$ ) } \\
\hline \multicolumn{4}{|c|}{ Drying (drying oven, $110^{\circ} \mathrm{C}, 3$ hours) } \\
\hline \multicolumn{4}{|c|}{ Firing (muffle furnace, $1,250^{\circ} \mathrm{C}, 2$ hours) } \\
\hline \multicolumn{4}{|c|}{ Grinding (planetary mill, $20 \mathrm{~min}$.) } \\
\hline \multicolumn{4}{|c|}{ Moistening press powder with carboxymethylcellulose solution $(W=8 \%)$} \\
\hline \multicolumn{4}{|c|}{ Formation (semi-dry pressing, $20 \mathrm{MPa}$ ) } \\
\hline \multicolumn{4}{|c|}{ Drying (drying oven, $110^{\circ} \mathrm{C}, 3$ hours) } \\
\hline \multicolumn{4}{|c|}{ Firing (silica oven, $1,250^{\circ} \mathrm{C}, 2$ hours) } \\
\hline
\end{tabular}

Fig. 5 The developed technological scheme for the radiotransparent ceramics creation

5. ábra A sugárzás áteresztő kerámiák készitésére kidolgozott technológiai eljárást bemutató folyamat ábra

\section{The discussion of the results}

According to the results of comprehensive studies, the following technological parameters of production are recommended: slavsonite firing at the stage of synthesis at a temperature of $1,250{ }^{\circ} \mathrm{C}$ with an hour-long exposure; fusion products grinding for 20 minutes in a planetary mill to get particle sizes of not more than $0.15 \mathrm{~mm}$; moisturizing with $4 \%$ solution of methylcellulose to become $8 \%$ the powder moisture; forming of semi-finished by semi-dry pressing at a pressure of $40 \mathrm{MPa}$; products' firing at a temperature of 1,350 ${ }^{\circ} \mathrm{C}$ with an hour-long exposure.

The properties of the developed compositions of radiotransparent ceramics that meet the requirements for radiotransparent materials and the characteristics of GOST 20419-83 [10] for a similar material from celsian are shown in Table 4. For the mass on the basis of the composition " 0 " with the addition of 1 wt. $\% \mathrm{Li}_{2} \mathrm{O}: \mathrm{SnO}_{2}$ the marking HRC-0 was made, and for the mass based on the composition " 2 " with the addition of 1 wt. $\% \mathrm{Li}_{2} \mathrm{O}$ the markings HRC-2 was made (HRC - high-temperature radiotransparent ceramics).

\begin{tabular}{|c|c|c|c|c|}
\hline Properties & HRC-O & HRC-2 & $\begin{array}{c}\text { GOST } \\
20419-83 \\
\text { (subgroup } \\
420 \\
\text { celsian) }\end{array}$ & $\begin{array}{l}\text { Require- } \\
\text { ments for } \\
\text { RTC }\end{array}$ \\
\hline $\begin{array}{l}\text { Apparent density, } \\
\mathrm{kg} / \mathrm{m}^{3}\end{array}$ & 2,960 & 2,880 & $\begin{array}{c}\text { Not less } \\
\text { than } 2,700\end{array}$ & $\begin{array}{c}\text { Not less than } \\
2,500\end{array}$ \\
\hline Water absorption, \% & 0.08 & 0.13 & 0.5 & Less than 0.1 \\
\hline $\begin{array}{l}\text { Dielectric permittivity } \\
\text { at } 1 \mathrm{kHz}\end{array}$ & 6.42 & 6.07 & - & Less than 10 \\
\hline $\begin{array}{l}\text { Tangent of dielectric } \\
\text { loss angle at } 1 \mathrm{kHz}\end{array}$ & 0.017 & 0.012 & $\begin{array}{l}\text { Less than } \\
10^{-2}\end{array}$ & $10^{-4}-10^{-2}$ \\
\hline $\begin{array}{l}\text { Specific volume } \\
\text { resistance, } \mathrm{Ohm} \cdot \mathrm{cm}\end{array}$ & $5.9 \cdot 10^{14}$ & $3.2 \cdot 10^{14}$ & $10^{14}$ & - \\
\hline Bending power, MPa & 72.3 & 62.4 & 80 & 60 \\
\hline $\begin{array}{l}\text { Operating } \\
\text { temperature, }{ }^{\circ} \mathrm{C}\end{array}$ & 1,500 & 1,300 & - & 1,200 \\
\hline
\end{tabular}

Table 4 Properties of the optimal compositions of radiotransparent ceramics 4. táblázat Az optimális sugárzás áteresztö kerámia összetétel tulajdonságai

\section{Conclusions}

Compositions of raw materials and technological principles of the ceramic radiotransparent materials manufacturing from them have been developed. According to the results of comprehensive studies, the following technological parameters of production are recommended: Slavsonite firing at the stage of it synthesis at a temperature of $1,250{ }^{\circ} \mathrm{C}$ with an hourlong exposure; fusion products grinding in a planetary mill for 20 minutes to get particle sizes of not more than 0.15 $\mathrm{mm}$; moisturizing with $4 \%$ solution of methylcellulose to become $8 \%$ the powder moisture; forming of semi-finished by semi-dry pressing at a pressure of $40 \mathrm{MPa}$; products' firing at a temperature of $1,350{ }^{\circ} \mathrm{C}$ with delay with an hour-long exposure.

The developed materials are characterized by the following properties:

- the HRC-2 composition: dielectric permittivity is $\varepsilon$ $=3.67 \ldots 4.12$ and the dielectric loss tangent is $\tan \delta=$ $0.0073 \ldots 0.0091$ (at $26-37.5 \mathrm{GHz}$ ) water absorption is $0.13 \%$; apparent density is $2,880 \mathrm{~kg} / \mathrm{m}^{3}$; flexural strength is $62.4 \mathrm{MPa}$; volume resistance is $1.1 \cdot 10^{13}$ $\mathrm{Ohm} \cdot \mathrm{cm}$ ); maximum temperature of operation is $1,200{ }^{\circ} \mathrm{C}$;

- the HRC-0 composition: dielectric permittivity is $\varepsilon=$ $4.93 \ldots 5.26$; the dielectric loss tangent is $\tan \delta=0.0097$ ... 0.0122 (at $26-37.5 \mathrm{GHz}$ ) water absorption is $0.08 \%$; 
apparent density is $2,960 \mathrm{~kg} / \mathrm{m}^{3}$; flexural strength is $72.3 \mathrm{MPa}$; volume resistance is $5.9 \cdot 10^{14} \mathrm{Ohm} \cdot \mathrm{cm}$; maximum operating temperature is $1,500{ }^{\circ} \mathrm{C}$.

The resulting materials comply with the requirements of GOST 20419-83 for products made of Celsian ceramics (class 420 ) and meet the requirements for radiotransparent materials.

\section{References}

[1] Lisachuk, G. - Kryvobok, R. - Zakharov, A., et al. (2017): Influence of complex activators of sintering on creating radiotransparent ceramics in $\mathrm{SrO}-\mathrm{Al}_{2} \mathrm{O}_{3}-\mathrm{SiO}_{2}$. Eastern-European Journal of Eenterprise Technologies, Vol. 1, № 6 (85), pp 10-15. https://doi.org/10.15587/1729-4061.2017.91110

[2] Romashin, A.G. - Gajdachuk, V.E. - Karpov, Ya.S. - Rusin, M.Yu. (2003) Radioprozrachnye obtekateli letatel'nyh apparatov. Proektirovanie, konstrukcionnye materialy, tekhnologiya proizvodstva, ispytaniya. ucheb. posobie, Nac. aehrokosm. un-t «Khar'k. aviac. in-t», Khar'kov. - 239 p.

[3] Goleus, V. I. - Karasik, O. V. - Homenko, O. S. (2017): Rozrobka sklokeramiki kordieritovogo skladu, Recent Studies of Applied Sciences, № 2, pp. 1-4.f3

[4] Bansal, N. P. - Drummond, C. H. (1993): Kinetics of hexacelsian to celsian phase transformation in $\mathrm{SrAl}_{2} \mathrm{Si}_{2} \mathrm{O}_{8}$. Journal of the American Ceramic Society, Vol. 76, № 5, pp. 1321-1324. https://doi.org/10.1111/j.1151-2916.1993.tb03758.x

[5] Sung, Y.M. - Kwak, W.C. (2002) Influence of various heating procedures on the sintered density of Sr-celsian glass-ceramic. Journal of Materials Science Letters, 21, №11, pp. 841-843. https://doi.org/10.1023/A:1015710309425
[6] Uvarova, N.E. - Orlova, L.A. - Popovich, N.V. (2008) Nizkotemperaturnyj sintez besshchelochnoj alyumosilikatnoj steklokeramiki. Uspekhi $v$ himii $i$ himicheskoj tekhnologii, Vol. 22, № 7(87), pp. 59-62.

[7] Shchukina, L.P. - Bolyuh, V.F. - Ligezin, S.L., ta in. (2018) Vpliv metodu konsolidaciï poroshkiv na fazoutvorennya tekhnichnoï keramiki, Integrovani tekhnologiï ta energozberezhennya. № 3, pp. 3-7.

[8] Shchegoleva, N.E. - Grashchenkov, D.V. - Sarkisov, P.D. i dr. (2012) Vliyanie dobavok $\mathrm{V}_{2} \mathrm{O}_{3}$ i $\mathrm{R}_{2} \mathrm{O}_{5}$ na kristallizacionnuyu sposobnost' stroncijalyumosilikatnogo stekla, Tekhnika i tekhnologiya silikatov. Vol. 19, № 2, pp. 7-14.

[9] Lisachuk, G.V. - Krivobok, R.V. - Zaharov, A.V. i dr. (2015) Intensifikaciya processa spekaniya Sr-keramiki putem vvedeniya mineralizatorov spekaniya, Kosmicheskaya tekhnika. Raketnoe vooruzhenie. № 3, pp. 74-78.

[10] Materialy keramicheskie elektrotehnicheskie. Klassifikatsiya i tehnicheskie trebovaniya: GOST 20419-83. - [Deystvuet s 1985-01-01]. - M. Mezhgosudarstvennyiy sovet po standartizatsii, metrologii i sertifikatsii, 1985. $-9 \mathrm{~s}$.

Ref.:

Lisaschuk, G. V. - Kryvobok, R. V. - Zakharov, A. V. - Chefranov, E. V. - Lapuzina, O. M. - Voloshchuk, V. V. - Samoilenko, N . N.: Technological parameters of ceramics creation on the basis of slavsonite

Építőanyag - Journal of Silicate Based and Composite Materials, Vol. 71, No. 2 (2019), 46-51. p. https://doi.org/10.14382/epitoanyag-jsbcm.2019.9

\section{5th World Congress on Materials Science \& Engineering} Materials Science and Engineering August 22-23, 2019, Valencia, Spain

In keeping with the Scientific Future Mission to aid the creation and sharing of Materials Science knowledge and experience, we are proud to announce the 5th World Congress on Materials Science \& Engineering, taking place in August 22-23, 2019 at Valencia, Spain. Focusing on the high impact topics of Material Science Engineering, Biomaterials, Nanoscience and Technology, Materials for energy and Advanced Materials and processing.The conference will bring together hundreds of leading researchers to share and discuss cutting edge research and engage in high level debate. Participants will include prominent researchers from academia and industry, and the meeting will provide a rare networking opportunity to meet leaders and peers working on solutions to some of the key issues facing materials scientists today.

http://worldmaterialsconference.com/2019 